\title{
Service delivery in Belhar? Leadership challenges between the real and the ideal
}

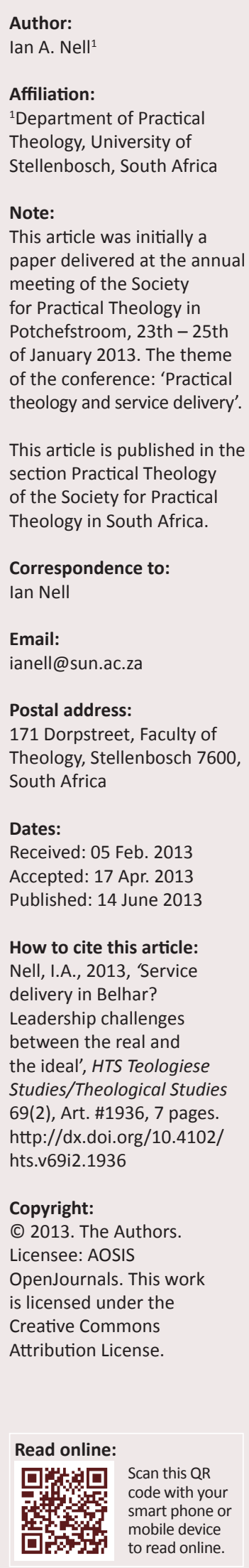

In the discipline of practical theology, one finds a long history of linking the name of the field to diaconiology, in which you find the Greek word diaconia, directly translated as 'service'. For good and scientific reasons, the field changed its name to practical theology in some Faculties of Theology but that does not take away the fact that this field of research is still very much engaged in the broad area of 'service of all kinds'. The purpose of this article was to do a descriptive investigation into the problems and challenges of service delivery in the suburb of Belhar (Cape Town), specifically looking at the role of leadership during a (new) time of struggle. As part of the normative task, the researcher took a closer look at the Belhar Confession as a prophetic stance in this regard. In an ironic twist, we see in these events the struggle between the real and the ideal that is typical of many places in the country facing problems with service delivery.

The Church often thinks it knows what the world wants from it - inspiration, 'leadership,' clear teaching. But surely what the world is most hungry for is the simple knowledge that healing is possible - not by forgetting or minimizing outrages and sufferings but by sheer, obstinate, costly commitment to work with the grain of grace. (Rowan Williams, Archbishop of Canterbury, in Lapsley 2012:i)

\section{Introduction}

The relationship between practical theology and 'service' comes a long way. The Departments of Practical Theology in the Faculties of Theology at Stellenbosch University and the University of the Free State initially functioned as departments of 'diaconiology' in which you hear the Greek word 'diaconia', directly translated as 'service'. It was only in later years that governing bodies changed the name of these departments to that of Practical Theology. In European countries like Germany they still do have a strong emphasis on the 'diaconical work' of the church with the Institute for the Study of Christian Social Service at Heidelberg University as one of the better-known examples in this regard.

In South Africa, we have been experiencing an acceleration of problems relating to 'service delivery' during the past two decades. ${ }^{1}$ Some commentators even describe it as one of the biggest challenges facing post-apartheid South Africa. ${ }^{2}$ According to the Multi-level Government Initiative's Service Delivery Protest Barometer (Multi-level Government Initiative [MLGI] 2012:4), by August 2012, there had already been 226 strikes, more than in any previous year. Practical theologians are not only interested in these kind of everyday practices influencing the life and dignity of ordinary citizens, but they also cannot ignore the close association between 'service', that is diaconia (serving the neighbour in need), and everyday 'service delivery' (supposedly to be provided by government to every neighbourhood in the country as a prerequisite for living a life of dignity).

In the Western Cape, the service delivery protests in the neighbourhood of Belhar became very prominent during the past year, giving another reason to probe, as practical theologians, the problems and challenges of this destabilising phenomenon in greater depth. The motivation for analysing the problem in Belhar lies in the fact that it was the precise neighbourhood in which the famous Belhar Confession was formulated 26 years ago at the General Assembly of the then Dutch Reformed Mission Church. It is a confession containing important confessional statements on the significance of unity (dignity), reconciliation and justice for South African churches in a context of violence and crisis and therefore of special importance in a new context of unrest.

\section{Statement of the problem and purpose of the study}

The article tries to find an answer to the practical-theological question ${ }^{3}$ : What lies behind the service delivery protests in South Africa, specifically within the neighbourhood of Belhar in 1.Some scholars even refer to the challenge of service delivery as the 'new struggle' in South Africa, cf. Botes et al. (2007).

2.See the emphasis that someone like Trevor Manuel (2011) places on this challenge in the National Development Plan and in a recent contribution to the web page leader.co.za under the heading: 9 major problems facing South Africa.

3.Practical theologians are interested in praxis, thus theory-laden everyday practices that influence people's lives and originate from deeper value systems. 
the Western Cape? The purpose of the article is to come to a better understanding of this phenomenon and to try to see if there are theoretical perspectives that can help us to understand what is happening and why it is happening? Theological (normative) reflection will be undertaken in the light of insights from the Belhar Confession, before looking at the role that leadership can play in addressing the challenges associated with bad service delivery.

If we can compare the service-delivery problems with a deadly virus causing a serious kind of illness in the South African society, we first want to see if we can come to some description of the symptoms before trying to understand what the origin and deeper causes are. After the diagnosis of the illness, we shall use the Belhar Confession as description of a healthy society ${ }^{4}$ before giving attention to some medicine for cure.

\section{The symptoms}

Looking for symptoms for this virus of poor service delivery, we observe, firstly, the violent nature it took on during the past year. Jooste (2012) concurs with this symptom in his description of the escalation of protests during the last couple of years and came to the conclusion that the protests definitely became more violent during 2012. ${ }^{5}$ The MLGI (2012) concurs:

Violent demonstrations are defined here as protests where some or all of the participants have engaged in actions that create a clear and immanent threat of, or actually result in, harm to persons or damage to property. (p. 5)

The protests are not only a danger for all of the inhabitants of the Western Cape but also do have a direct impact on the security and peace of people living in Belhar and the surrounding suburbs. According to the MLGI barometer, $79.2 \%$ of the protests in 2012 turned violent with the highest incidence in the Western Cape (MLGI 2012:6). The escalation of violent protests is an outcry of communities for better living conditions, for basic human rights and to be treated with human dignity. It normally comes from a situation of hopelessness and powerlessness.

According to the census of $2001^{6}$, Belhar had a population of 49404 , of which the majority of residents were between 18 and 54 years of age. In Belhar, $77.5 \%$ of the residents do have a job, and most of them work in the following categories: education $(17.9 \%)$, clerks $(16 \%)$, manual labour and trade (15.1\%), machine operators (12.4\%) and technicians (1.1\%). Furthermore, $83.4 \%$ of residents do have brick houses on private property whilst $7.7 \%$ reside in various forms of informal settlements. In addition, $97.8 \%$ of residents use electricity, $90.65 \%$ have access to water inside their homes and $94.7 \%$ have a flush toilet connected to a sewage system. In the

4.When I refer to a "healthy society', I am not proposing that the Belhar Confession should be seen as a blueprint for the construction of a healthy society. The Belhar Confession remains the confession of certain convictions held by a faith community based on an understanding of Scripture. What I am convinced of is that the Belhar Confession helps us with theological language in addressing societal illness.

5.In an interesting contribution by Manala (2010:523), he ascribes the use of police brutality in dealing with the protests as one of the main reasons for the high levels of violence, as this 'fuels the frustration and anger of communities leading to violence'.

6.I take 2001 as point of reference because of two reasons. It was the last of the population data that was fully processed, and it also gives a time span of 12 years to help to understand what happened in the community from a historical perspective. suburb, $99.6 \%$ of the residents' rubbish is removed weekly. In the area of Kuils River and Belhar, $80 \%$ of residents associate themselves with Christianity. On the surface, it looks as though, in 2001, service delivery in Belhar was sufficient. The question is then: What changed during the past 11 years?

Unfortunately the statistics of the 2011 census have not been processed to articulate Belhar's current situation in detail. However, some conclusions can be drawn. In 2001, 48\% of residents had an income of between R19 201 and R76 800 per household per year. In 2011, the average household income in the Western Cape increased by 113.3\% (or R103 204 per year) (Statistics South Africa 2011:36). This means that the monthly income in 2011 ranged between R1600 and R6400. However, the monthly increase in income during the past 10 years did not have a significant impact on poverty in the community. In addition, inflation grew by 32.16\% since 2001 . The population also increased by $28.67 \%$ between 2001 and 2011 (Statistics South Africa 2012).

It is clear that, between 2001 and 2011, drastic changes occurred in the Western Cape, which undoubtedly affected service delivery. In South Africa, poverty is a daily reality. Williams defines poverty as a complex manifestation of physical and spiritual pain that breaks down the human dignity of individuals and communities (as quoted in de Klerk 2006:41). Statistics South Africa (2012) clearly emphasises the fact that Cape Town is one of the cities that is experiencing the greatest population growth and urbanisation. They also argue that there is a strong statistical relationship between population growth and problems with service delivery.

\section{Looking for causes}

We can elaborate on the symptoms, but from the facts just described, it is obvious that we do have at hand a serious illness in the Belhar-community. In looking for causes, we can start with the information given by the MLGI. The issues which gave rise to the protests were hierarchically motivated by the MLGI (2012:6) in the following order:

1. land and housing

2. water and poor service delivery

3. electricity

4. ignored grievances

5. infrastructure.

Most of the protests thus deal with land and housing issues whilst poor service delivery lies second on the list. Interesting is that party-political issues are the least cited overall, making up only $6.19 \%$ of the total number of grievances (MLGI 2012:7).

Jooste (2012) describes the incidences of violent protest because of service-delivery problems by quoting Jaap de Visser (one of the editors of the MLGI) who attributes part of the problem to the political struggle between the Democratic Alliance (DA) and the African National Congress Youth League (ANCYL). Patricia de Lille also argues that the protests are a clear political strategy of the ANCYL. Okecha (2011:96) argues that political forces have a real impact on the socio- 
economic condition of their ruling environments. Politicians have the power to shape the urban environment through partnerships that include the policies they implement and their ties to the national government. The other possibility is that the services improved but that the community did not recognise it.

However, the more one read about the problem, the more it becomes apparent that the problem is not only political in nature but multi-faceted with different factors contributing to the illness experienced. Therefore the caution by De Visser and Powell must be taken seriously:

It is of paramount importance to develop a nuanced understanding of service delivery protests as they are becoming an enduring feature of South African society ... with regard to the grievances raised by protesters, the picture remains complex. It is clear that the protesters raise a variety of issues and many of them relate to municipal services and governance. (MLGI 2012:7)

Making use of Talcot Parsons' action theory ${ }^{7}$, I want to arrange the causes for the service-delivery problems by concentrating on the four factors that he distinguishes within social systems $(\mathrm{AGIL})^{8}$, namely:
(A) the economic system: money
(G) the political system: political power
(I) the societal community: influence
(L) the fiduciary system (cultural tradition): value commitment

\section{Economic factors (money)}

Sacks wrote the following in the Mail \& Guardian of 21 September 2012, under the heading A political truth about civil disobedience:

It is clear that the protesters are responding to the structural violence of the state, to the structural violence of a society that hates the poor, that denies them livelihoods and leaves them landless, homeless and living in appalling conditions.

Various political and elitist groups see the poor communities as a burden and embarrassment. We read about several groups of poor people around the country that keep complaining about their conditions almost 20 years into the post-apartheid South Africa.

Income inequality ranks highly amongst the structural determinants of the protests. In 2009, after 15 years of democratic rule, the country's Gini-coefficient was still one of the highest in the world (United Nations Development Programme [UNDP] 2009:197). Recent government statistics show that, between the end of apartheid and 2008, poverty and inequality had remained major challenges for South Africa. Using the Gini-coefficient, inequality worsened from 0.64 in 1994 to 0.66 in 2008. The driver of the increase in inequality has been between-group inequality (The Presidency 2010:25).

The ever-increasing unemployment trend, which has followed in the wake of the global financial meltdown resulting in hundreds of thousands of job losses, will have expanded action theory, working with four factors.

8.AGIL is the acronym or letters that Parsons uses for all living systems: (A) Adaptation (G) Goal attainment, (I) Integration and (L) Latent function or pattern maintenance. inequality and intensified problems of survival (Friedman 2012:87). According to the Quarterly Labour Force Survey (Statistics South Africa 2012:xiv-xvii), total unemployment rose by 282000 in 2012, reaching 4.5 million, representing 25.2\% of the entire adult population. However, between 2008 and 2012 , the unemployment rate increased amongst the Coloured (2.8\%), Black (1.4\%) and Indian/Asian population (0.8\%) whilst it decreased amongst the White population (0.6\%).

In a very informative article with the title Rebellion of the poor: South Africa's service delivery protests - a Preliminary analysis, Alexander (2010:25-40) describes how extensive and militant the service-delivery protests have become in certain areas and describes this phenomenon as a rebellion of the poor. He points to similarities in the protests during the Mbeki and Zuma eras mainly associated with inadequate service delivery and the lack of accountability on the part of local councillors. The big difference is that the government now enjoy greater legitimacy, but this legitimacy ironically also increases the level of protest as many people belief that Zuma better understands their grievances and can indeed do something about it. In that sense, the protests reflect a disappointment in the fruits of democracy.

Alexander (2010:37) believes that most of the problems must be directed at the post-apartheid government's policy that can be described as neo-liberal. The privatisation of public services led to new opportunities for the private accumulation of wealth by local councillors with the consequence that neoliberalism maintained inequality. The latter, together with the policy of economic empowerment, contributed to a sense of injustice.

The level of unemployment is currently also higher than in 1994, and the huge differences in income remain the same. After discussing various possible future scenarios, Alexander (2010) came to the following conclusion:

There is a dialectical relationship between the scale of a mass movement and its demands, but these are also influenced by political formations. For now, in South Africa, it is more likely that action will feed into the SACP and reform of the system than into development of a revolutionary movement. But the position can change, particularly given the relative youth of the new generation of activists. (p. 38)

From the discussion, it is quite clear that unemployment, poverty, income inequality and many other aspects all contribute to economic factors that have a direct impact on poor service delivery.

\section{Political factors (political power and policy)}

Bartlett (2012) indicates that the residents of Belhar started their protest in June 2012 because officials did not keep their promises to transfer the residents to a nearby housing project. The march became extremely violent, and the police had to intervene. Sacks (2012a) ascribed the protests to residents' experience that their quality of life has not improved since 1994 and that both the DA and the ANC did not listen to their requests. He (Sacks 2012b) comes to the conclusion that 
communities fight in a legal way for their socio-economic rights, participate in legitimate protests and even becomes violent, but it has no impact on the ruling powers. Unfulfilled promises and the ignoring of their requests contribute greatly to the discontent and the protests. The only strategy left to the community is to protest and in this way sensitise other communities living in the same conditions in order to be heard. Though the only option left to these communities, violent protests have the negative effect that the security and peace in the communities become very problematic.

In an insightful study, Okecha (2011:55-110) makes use of Urban Regime Theory ${ }^{9}$ to illustrate the tremendous impact that the local conflict between different political parties have on service delivery. It is clear that these conflicts take the form of shifting political alliances with different agendas on how the city should be governed. The conflict is mainly between the ANC, the DA and independent groups. Urban Regime Theory helps one to see how much attention opposition politics between different parties receives on a national level. However, the role that these conflicts play at a local level has not yet been researched thoroughly.

Okecha (2011:108) concluded that the local political conflicts have a direct impact on service-delivery problems in the greater Cape Town metropolitan area. Regime politics show how the complex relationships in some political conflicts determine the quality and stability of the political order and how the actors involved are responsible to construct the political arena. Political coalitions are often unstable and realign themselves with the changing times and circumstances. In Cape Town, the changes that occurred with every regime change between 2000 and 2008 caused new policies as well as the rejection or disapproval of existing projects and their replacement with others. The lack of execution of the policies destabilised the administration, and the loss of trained skills had a direct impact on service delivery. Urban Regime Theory shows how the promises that have been left unfulfilled had a direct impact on on-going community involvement.

\section{Psychosocial factors (integration)}

Louw (2007:117) points to the important underlying psychological fact that where basic human needs are not met (security, respect, freedom and personal power) frustration builds up. In the process of satisfying these basic needs, the victims of poor service delivery identify with the methods of the aggressor and thus with violence as the only means to achieve their goal. In the process of looking at means and ways to address these basic human needs, there is unavoidably and escalation in violence.

Smelser's theory of collective behaviour helps to provide answers to the question as to why communities become

9. Urban regime theory holds potential for explaining the variety of arrangements through which policymakers in cities have coped with change, because of its through which policymakers in cities have coped with change, because of its sensitivity to local conditions and local actors. Its essential contribution is to focus attention on the collective action problems that have to be overcome for effectiv urban governance to emerge. The nature of the collective action challenge varies according to the purpose, composition, and position of potential regime partners. Substantial differences in motivating factors must be taken into account in order to apply regime analysis cross-nationally' (Stoker \& Mossberger 1994:195). violent. According to this theory (Marx \& Wood 1975:410-414), there are six conditions for collective behaviour to take place:

1. structural conduciveness, or the permissiveness of social arrangements

2. structural strain, or existence of ambiguities, deprivations, tensions, conflicts and discrepancies in the social order

3. the growth and spread of generalised beliefs, or the existence in the population of beliefs that identify the source of strain, attribute certain characteristics to the source and specify certain responses to the potential participants

4. precipitating factors, or the occurrence of some type of specific event that gives the generalised beliefs concrete substance

5. mobilisation of participants for action, or the organisation of the effected group into action

6. the ineffective operation of control, or the ineffectiveness of the social counter-determinants that prevent, interrupt or inhibit the accumulation of the other five determinants of collective behaviour.

One of Smelser's (1963:28) main arguments is that there are four components of action, causing five types of collective behaviour. This means that, when a specific component of action is under stress, a certain type of collective conduct can be predicted but with the prerequisite that the other components of collective behaviour are also in play, Marx and Wood (1974) indicate:

The four components of action are:

1. Values, or desirable ends which guide any human endeavor;

2. Norms, or the more specific rules of conduct which guide action;

3. Mobilisation of motivation into organised action, or motivation of the agents who will pursue the desired ends and follow the rules;

4. Situational facilities, or 'the means and obstacles which facilitate or hinder the attainment of concrete goals in the role or organizational context' (Smelser 1963:28). The main types of collective behavior are the panic, the craze, the hostile outburst, the norm-oriented movement, and the value-oriented movement. (p. 413)

The components of Smelser's theory can clearly be observed in the protests in Belhar. We see collective behaviour that seeks changes in service delivery and in the process involve other people of the community who also feel disadvantaged and then start to participate in this collective action. Escapist behaviour starts when the protests become violent, and the participants feel trapped and start to panic. This often leads to further violence and offensive behaviour.

According to Smelser's theory (Gergen \& Barton 1974:569), the behaviour of the community can contribute to either peace or damage to property. Since the theory argues that this behaviour is non-normative, it is important to ask ourselves the question: Under what circumstances does the group's normative behaviour change to non-normative? As a result of unfulfilled promises, poverty and service-delivery problems that were not addressed, the Belhar community faced structural tension. The tension and collective behaviour to reach a common goal, namely changing their servicedelivery problems, motivated the community to stand up against the existing structures. 
The social mechanisms, in this instance in the form of the DA, was not able to prevent the protests with the result that the ANCYL and of the Belhar community mobilised themselves. Because of the non-normative behaviour of the collective group, it was seen as a threat. Such behaviour also often leads to violent protests that lead to panic and the sabotage of service delivery. It is therefore clear that a group's normative behaviour change to non-normative behaviour because of cultural influences on the group, the personal attitude and satisfaction and the effective fulfilment of their needs.

\section{Factors related to cultural traditions and value commitments (identity)}

Pithouse (2011) writes about what he calls the service-delivery myth, arguing that justice and compensation are in many instances just a case of technical adjustments imposed by the state on poor people waiting to be channelled into the network of service with the hope of a better life. He argues that the situation is much more complicated than that because our current situation, as the result of many factors, causes new inequalities with the net result that the number of people living in informal housing is growing by the day. That is the case in spite of the fact that two million houses have been built by the post-apartheid government. The fact that a house has been built is not saying anything about the quality, location and size of the dwelling as well as who lives in it and the way in which it has been allocated.

Van Wyk (1990:103-104) refers to the social contract theory of Rawls, based on the common idea of justice for all. This justice is violated by the impairment of the two principles of justice, namely freedom and equality. Each person must be free to the degree that her or his freedom can be reconciled with the freedom of another person. Social and economic injustices must be managed in such a way that it can be reasonably expected that they will benefit all. They should be linked with the possibility for each and every one to be appointed in the available positions and offices. Life opportunities do have to be equal and one group cannot always be on the receiving end. Rawls (in Van Wyk 1990:103) is of the opinion that civil disobedience is acceptable if there is a serious violation of the first principle and when the second principle if blatantly violated.

The result of all the different factors discussed in this section is what Uslaner (2002) calls 'a lack of trust'. He argues convincingly that the relationship between social trust, trusting human beings in general and service delivery is a complex business. This lack of social trust can be addressed when we look at the deeper sources of wisdom. In the case of the Christian faith, it will be a case of finding theological language pointing to the basic human need to trust in God.

\section{A healthy society?}

In this same neighbourhood of Belhar, of which we have just strained to understand the reasons behind the protests against poor service delivery, the General Synod of the Dutch
Reformed Mission Church gathered 26 years ago (1982) for their quadrennial assembly. A document that became known as the Belhar Confession was drafted and finally adopted as a fourth confession by the Church in 1986.

Smit (2011:11) points to the fact that the document was developed in a historical context of suppression (apartheid) and that the meeting of the Synod had the important task to discern whether they were hearing the gospel correctly. In that sense, it was a deeply contextual but also a deeply theological event. Confessions of faith, like the Confession of Belhar, are the application of the Christian faith in new and concrete situations (Smit 2011:1).

Naudé (2010) summarises the confession in the following way:

The confession consists of five subsections ... The first article repeats and confirms the ancient Christian belief in the triune God, who establishes the church. The following three articles deal with the church and its role in the world: the unity of the church (art. 2), reconciliation in the church and society (art.3), and the bringing about of peace and justice in the world (art. 4). The fifth article calls the church to do what is confessed, even if it means persecution. The confession closes with a brief doxology to God. (p. 5)

Clause 4, however, is especially useful in answering the challenge of the current situation faced by the community. De Gruchy (2007:361) says that this clause takes the confession beyond the obvious rejection of Apartheid, based on what might be construed as 'individual' unity and reconciliation, to the question of social and political justice. Here the authors are clear that the fundamental issue with Apartheid is not just about the integrity of the church in a 'churchy' way but also about its integrity in the public arena.

It makes the bold claim that God 'is in a special way the God of the destitute, the poor, and the wronged and that he calls his Church to follow him in this' (Confession of Belhar 1986:4-5). In this way, one understands that God is always on the side of the marginalised and oppressed and against the oppressor and subjugator. God is always on the side of the just and exploited and against the unjust and exploiter. God is on the side of the poor precisely because they are vulnerable and victimised. As such, the Belhar Confession could function as a governing paradigm in which to interpret and frame the theological and normative reflections on the problem.

An important contribution to the normative reflection on poor service delivery comes from the context of 'Black Theology in South Africa' with Manala (2010:519) who argues that it is the black masses in the country that continue to suffer profoundly from 'the lack of basic services in their townships and informal settlements.' We find in Manala's argument (2010:520-525) a strong moral judgement on the current state of public service delivery with a robust critique of the degree to which corruption and greed amongst local government employees are disenabling service delivery, contributing to the injustices that the Belhar Confession addresses. 


\section{Possible prescriptions for cure}

In looking for possible prescriptions for the cure to bad service delivery and expecting leadership to take the necessary action between what we discovered as the real and the ideal, the six different forms of the church to which Smit (2004) refers can be a good starting point. It also helps us to understand that it is possible to develop different types of leadership within each of these forms.

It starts with the church in prayer and worship because Christians approach everyday life and all of its challenges from a relationship with God. In prayer and worship, we bring our deepest desires, complaints and gratitude to God, reflecting the needs in our lives (Smit 2004:352). According to Smit (2004:352), we already experience a foretaste of the new reality that God provides, and we can cling to the promises of God as we become more aware of the world's needs. Through prayer, we become aware of our own needs in terms of poor service delivery, poverty, indignity and insecurity but also the needs of others (Smit 2004:353). One way of showing our compassion for the needy is through our prayer life. Leadership in the person of the liturgist and preacher can play an important part in bringing the problem to the attention of the members of the congregation.

Secondly, we are part of congregations as living communities, operating as living bodies that work to relieve the suffering of others (Smit 2004:354). Therefore, we as a church community take it upon ourselves to care for the needy. Leadership in the persons of the chairperson, the board members and the committee involved with charity and outreach can play an important role in this regard.

The role of communities of faith links with the third aspect, namely that we need not tackle the task alone. Faith communities are also part of bigger bodies like circuits and Synods where we join efforts in addressing these challenges. Congregations are not supposed to be self-centred in their existence but stand in relationships with one another. Through these networks of relationships, we affirm our Godgiven value to each other, and together we can fight injustice and poverty (Smit 2004:355). As we saw in the discussion, the causes and effects of poor service delivery, poverty, human dignity and security are complex issues that we cannot tackle on our own. Leadership through these bodies, their chairpersons and activities can make a huge contribution to the problem of service delivery.

This brings us to the fourth aspect, namely that we are also embedded in various other networks of Christian commitments, and therefore, we can stand together against a challenge like poor service delivery (Smit 2004:357). According to the theory of collective behaviour, a strong ecclesiastical system can serve as some sort of a mechanism of social control and prevent violent protests (we saw this during the apartheid years). This will only happen if the system enhances structural stability and thus helps to address the needs of the community. If this happens, communities will no longer be unconsciously dragged into the current political power play and collective behaviour, but they will create a new collective attitude in which their dignity in God and in each other are grounded. They will then be in the position to address servicedelivery issues in peace and safety. Leadership by way of networking with other civil-action groups that are working through dialogue and liaison can play a very important part in addressing the problem.

Fifthly, it also means that each individual need to take responsibility in practical ways to contribute to the processes of service delivery (Smit 2004:358). It must be acknowledged that service delivery, because of the enormous population growth, is under tremendous pressure, and if everyone plays their part, it will reduce the pressure. In addition, it is also possible to do your work in the community by serving your neighbour as a disciple and by not selfishly and slavishly respond to the consumer culture (Smit 2004:359).

The sixth and final aspect relates to the fact that the community of Belhar is part of civil society and that part of our calling as a church involves the way in which we deal with poverty, how we show compassion and the peaceful way in which we are all working together to build a better society (Smit 2004:360). God's solidarity with the victims of injustice is a confirmation of lives that can and will be renewed. This solidarity overcomes the helplessness of poverty, indignity and poor service delivery. Our participation as individual members in the activities of civil society, serving on committees and boards, are ways of exercising leadership as service to the community.

In this way, God's solidarity is not only condemnation of insensitivity and oppression but also mercy for all who are affected by it. God gives us a faith community to address the immanent needs through God's transcendental reality. In the words of Osmer (2008:12), we can call it a 'spirituality of priestly presence'. Instead of leading to violent acts, it is our responsibility to join hands in Christian love with the rest of the community to work constructively towards better service-delivery structures. ${ }^{10}$

\section{Conclusion}

The open wounds of protests against bad service delivery affect all of us. There is no way that we can look the other way or try the ostrich trick. The leadership challenges between the real and the ideal in situations like this is complex and varied as I tried to prove in the argument of the article. Every day, we hear on the news and see on TV how the disease is spreading all over our country. In the newest statistics (Statistics SA 2012) on population demographics, we see that two thirds of people in South Africa live in urban areas, placing enormous pressure on service delivery.

10.Naudé (28 Sept 2012) wrote an article with the heading 'South Africa's leadership crisis' in which he refers to three things that are central in exercising leadership, especially within the context of poor service delivery: vision (what do we see visualise and dream of in our community), execution (taking initiative on different levels and dream of in our community), execution (taking initiative on different levels
through dialogical pedagogy), values (our deepest commitments - the Confession of Belhar is an example). 
We saw that it could easily culminate in what Uslaner (2002) calls 'a lack of trust'. We referred to the fact that he is convinced that the relationship between social trust, trusting human beings in general and service delivery is a complex business. We also tried to argue that this lack of social trust can be addressed when we look at the deeper sources of wisdom. In the case of the Christian faith, it will be a case of finding theological language pointing to the basic human need to trust in God.

\section{Acknowledgements Competing interests}

The author declares that he has no financial or personal relationship(s) which may have inappropriately influenced him in writing this article.

\section{References}

Alexander, P., 2010, 'Rebellion of the poor: South Africa's service delivery protests - a preliminary analysis', Review of African Political Economy 37(123), 25-40.

Bartlett, L., 2012, 'Belhar protests continue', Eyewitness News, 13 June, viewed 03 November 2012, from http://www.ewn.co.za/2012/06/13/Motivation-behindprotest-unclear

Belhar Confession, 1986, Confession of Belhar, viewed 08 November 2012, from http:// images.rca.org/docs/aboutus/BelharConfession.pdf

Botes, L., Molefi, L., Marais, L., Matebesi, Z. \& Sigenu, K., 2007, The new struggle: Service delivery-related unrest in South Africa, Centre for Development Support, Bloemfontein

De Gruchy, S.M., 2007, 'On not abandoning church theology: Dirk Smit on church and politics', Nederduitse Gereformeerde Teologiese Tydskrif 48(1), 356-365.

De Klerk, B.J., 2006, 'Liturgiese riglyne vir die sensitiefmaak van die jeug vir die probleem van armoede', Praktiese Teologie in Suid-Afrika 21(1), 39-60.

Friedman, S., 2012, 'Beyond the fringe? South African social movements and the politics of redistribution', Review of African Political Economy 39(131), 85-100. http:// dx.doi.org/10.1080/03056244.2012.658718

Gergen, K.J. \& Barton, W., 1974, Social psychology: Explorations in understanding, CRM Books, Menlo Park, C.A.

Jooste, B., 2012, 'Cape "has most violent protests"', Independent Online, viewed 07 November 2012, from http://www.iol.co.za/news/south-africa/western-cape/capehas-most-violent-protests-1.1401071

Lapsley, M., 2012, Redeeming the Past: My Journey from Freedom Fighter to Healer, Orbis Books, New York.

Louw, D.J., 2007, 'Cura Vitae': Illness and the healing of life in pastoral care and counseling: A guide to caregivers, Lux Verbi, Wellington.
Manala, M.J., 2010, “'A better life for all”: A reality of a pipe dream? A Black Theology intervention in conditions of poor service delivery in the democratic South Africa', Scriptura 105, 519-531.

Manuel, T., 2011, '9 major problems facing South Africa', in leader.co.za, viewed 10 November 2012, from http://www.leader.co.za/article.aspx?s=1\&f=1\&a=2893

Marx, G.T. \& Wood, J.L, 1975, 'Strands of theory and research in collective behaviour', Annual Review of Sociology 1, 363-428. http://dx.doi.org/10.1146/annurev. so.01.080175.002051

Multi-level Government Initiative (MLGI) 2012, 'Multi-level government initiative's service delivery protest barometer', Local Goverment Bulletin 14(3), 1-11. http://www.mlgi.org.za/publications/publications-by-theme/local-governmentbulletin/2012-local-government-bulletin-october-volume-14-issue-3

Naudé, P.J., 2010, Neither calender nor clock: Perspectives on the Belhar Confession, William B. Eerdmans Publishing Company, Grand Rapids.

Naudé, P.J., 2012, 'South Africa's leadership crisis', Business Day, 30 September, viewed n.d., from http://www.bdlive.co.za/opinion/columnists/2012/09/03/south-africasleadership-crisis

Okecha, K., 2011, 'Regime politics and service delivery in the Cape Town unicity council area', Urban Forum 22, 95-110. http://dx.doi.org/10.1007/s12132-010-9103-8

Osmer, R.R., 2008, Practical theology: An introduction, William B. Eerdmans Publishing Company, Grand Rapids.

Parsons, T., 1965, 'An outline of the social system', in T. Parsons, E. Shils, K.D. Naegele \& J.R. Pitts (eds.), Theories of society, pp. 30-79, Free Press, New York.

Pithouse, R., 2011, 'The service delivery myth', Development in Focus 1, 5-6, viewed 04 December 2012, from http://www.abahlali.org/files/DIF_Feb_2011-1.pdf

The Presidency, 2010, Development indicators 2010, viewed no date, from http:// www.thepresidency.gov.za/MediaLib/Downloads/Home/Publications/ NationalPlanningCommission4/Development\%20Indicators2010.pdf

Sacks, J., 2012a, 'Deep Read: The politics of protest', Mail \& Guardian, 21 August, viewed 09 November 2012, from http://mg.co.za/article/2012-08-21-the-politicsof-protests-in-cape-town

Sacks, J., 2012b, 'A political truth about civil disobedience', Mail \& Guardian, 21 September, viewed 08 November 2012, from http://mg.co.za/article/2012-09-20apolitical-truth-about-civil-disobedience

Smelser, N., 1963, Theory of collective behavior, Free Press, New York.

Smit, D.J., 2004, 'Oor die kerk en maatskaplike uitdagings in ons land', Nederduitse Gereformeerde Teologiese Tydskrif 45(2), 350-362.

Smit, D.J., 2011, "n Blik op eenheid, versoening en geregtigheid: 1986 en 2011', voordrag gelewer aan die Fakulteit Teologie, Universiteit van die Vrystaat, 31 Oktober 2011 , Bloemfontein.

Statistics South Africa, 2012, Quarterly labour force survey, Quarter 1, 2012, viewed 15 November 2012, from www.statssa.gov.za/publications/P0211/P02111stQuarter2012

Stoker, G. \& Mossberger, K., 1994, 'Urban regime theory in comparative perspective', Environment and Planning C: Government and Policy 12(2), 195-212. http://dx.doi. org/10.1068/c120195

United Nations Development Programme (UNDP), 2009, Human development report 2009, viewed 08 November 2012, from http://hdr.undp.org/en/media/HDR_2009 EN_Complete.pdf

Uslaner, E.M., 2002, The moral foundations of trust, Cambridge University Press, New York.

Van Wyk, C., 1990, 'Burgerlike ongehoorsaamheid of gewelddadige verset?', in B.J. Van der Walt (red.), Venster op mag en geweld: Christelike perspektiewe, bl. 165-174, Potchefstroomse Universiteit vir Christelike Hoër Onderwys, Potchefstroom. 